\title{
RHEUMATOID ARTHRITIS OF THE LUMBAR SPINE
}

\author{
BY
}

\author{
J. S. LAWRENCE, J. SHARP*, J. BALL, AND FRIDA BIER \\ From the Rheumatism Research Centre and the Empire Rheumatism Council Field Unit, University of Manchester
}

Although the radiological appearances of rheumatoid arthritis of the cervical spine are now well recognized there is little information on the changes, if any, to be expected in the dorsal and lumbar spine. We have encountered only three papers dealing with rheumatoid arthritis in this part of the spine. Baggenstoss, Bickel, and Ward (1952) and Lorber, Pearson, and Rene (1961) have reported rheumatoid granulomatous nodules in lumbar vertebrae with destructive changes and Seaman and Wells (1961) have observed fusion of two dorsal vertebrae after disappearance of the disk in a patient with rheumatoid arthritis.

\section{Method}

The present study is concerned mainly with radiological changes of rheumatoid arthritis in the lumbar spine. The method employed was identical with that used in devising criteria for cervical rheumatoid arthritis (Sharp, Purser, and Lawrence, 1958). Routine lateral $x$ rays of the lumbar spine from patients admitted to the Manchester Royal Infirmary with clinical evidence of rheumatoid arthritis and from persons having a positive sheep-cell agglutination test (SCAT) were used. The latter were discovered on routine testing of population samples in Leigh, Lancashire, and the Vale of Glamorgan, South Wales. These "rheumatoid" $x$ rays were compared with lumbar spine $x$ rays from the random samples as a whole; all those used in this study were of persons aged 55 to 64 years.

From this initial study certain diagnostic criteria for rheumatoid arthritis in the lumbar spine were determined and these were then applied in a blind reading by two observers of all radiographs of the lumbar spine in persons aged 55 to 64 years in the population samples in Leigh and the Vale of Glamorgan, each radiograph being graded 0-4 for rheumatoid arthritis. Subsequently 100 selected films were re-read twice by one observer to determine the extent of intra-observer differences in grading.

* Present Address: Withington Hospital, Manchester 20.

\section{Assessment of Criteria}

For the initial assessment of criteria the films of nineteen males and 31 females were used. Of these, eleven males and twenty females were hospital in-patients and the remainder were persons aged 55 to 64 from the population samples who had a positive sheep-cell agglutination test (SCAT) with or without other signs of arthritis. The hospital patients whose films were used for this study were suffering from disease of a severity similar to that in the patients whose films were used in the study of cervical rheumatoid arthritis, 27 being used for both studies. All except three had a positive SCAT. Of the nineteen sero-positive individuals from the random sample, six had clinical evidence of inflammatory polyarthritis, and four of the others had radiological evidence in the hands, feet, or cervical spine, so that altogether ten of the nineteen sero-positive persons from the population had evidence of rheumatoid arthritis. To obtain a suitable control group of equal size, individuals aged 55 to 64 were drawn at random from the population sample, and those with a positive SCAT, clinical evidence of inflammatory arthritis, or radiological evidence of erosive arthritis were sifted out.

In Table I (overleaf), the radiological findings in the control group are compared with those in the hospital patients and sero-positive members of the general population. Of the fifty 'non-rheumatoid arthritis' subjects, ten were miners. As miners have been shown to suffer more severely from disk degeneration than other workers (Kellgren and Lawrence, 1952) and, as this might interfere with the interpretation of the films, ten non-miners were later substituted. Certain data are shown in Table I both for the original $\left(b_{1}\right)$ and the partly substituted control group $\left(b_{2}\right)$.

All changes were graded $0-4$ for severity.

As the L5 disk and the apophyseal joints were not always clearly visible and indeed seldom proved important, it was decided to exclude them from the computations, which are therefore based on those five disks and pairs of apophyseal joints which occur between the 12th dorsal and 5th lumbar vertebrae. In this paper each disk will be designated by reference to the vertebra immediately above it. Thus, the disk between the 12th dorsal and the 1st lumbar vertebrae will be referred to as 
TABLE I

RADIOLOGICAL CHANGES IN THE LUMBAR SPINE IN 100 PERSONS ALL AGED 55 TO 64 YEARS

(a) Rheumatoid and/or Waaler-Rose + ve

(b) Non-rheumatoid, Waaler-Rose - ve

$\begin{array}{ll}\text { (b1) Original sample } & \text { (b2) } 10 \text { Miners replaced by non-manual workers }\end{array}$

\begin{tabular}{|c|c|c|c|c|c|c|c|c|c|c|c|}
\hline \multirow{3}{*}{$\begin{array}{c}\begin{array}{c}\text { Characteristic } \\
\text { Examined }\end{array} \\
\text { All }\end{array}$} & \multirow{3}{*}{$\begin{array}{c}\begin{array}{c}\text { Weighted } \\
\text { Score }\end{array} \\
\text { Total }\end{array}$} & \multicolumn{3}{|c|}{ Male } & \multicolumn{2}{|c|}{ Female } & \multicolumn{3}{|c|}{ Male and Female } & \multirow{3}{*}{\multicolumn{2}{|c|}{$\begin{array}{c}\text { Probability of } \\
\text { Difference RA/Non-RA } \\
\text { More in RA } \\
\text { More in Non-RA }\end{array}$}} \\
\hline & & \multirow{2}{*}{ (a) } & \multicolumn{2}{|c|}{ (b) 2} & \multirow{2}{*}{ (a) } & \multirow{2}{*}{$\frac{(b)}{31}$} & \multirow{2}{*}{ (a) } & \multicolumn{2}{|c|}{$1^{(b)} 2$} & & \\
\hline & & & 19 & 19 & & & & 50 & 50 & & \\
\hline Disk Narrowing & $\begin{array}{l}0 \\
1 \\
2 \\
3 \\
4 \\
5 \\
6\end{array}$ & $\begin{array}{c}7 \\
1 \\
5 \\
3 \\
2 \\
1 \\
\end{array}$ & $\begin{array}{l}4 \\
7 \\
4 \\
1 \\
2 \\
1 \\
\end{array}$ & & $\begin{array}{r}14 \\
4 \\
5 \\
5 \\
1 \\
1 \\
1 \\
\end{array}$ & $\begin{array}{r}15 \\
9 \\
4 \\
2 \\
1 \\
- \\
\end{array}$ & $\begin{array}{r}21 \\
5 \\
10 \\
8 \\
3 \\
1 \\
2 \\
\end{array}$ & $\begin{array}{r}19 \\
16 \\
8 \\
3 \\
3 \\
1 \\
\end{array}$ & & $\begin{array}{l}\mathbf{M}_{1} \\
\mathrm{~F} \\
\mathrm{M}_{1}+\mathrm{F}\end{array}$ & $\begin{array}{l}>\cdot 90 \\
<\cdot 16 \\
<\cdot 15\end{array}$ \\
\hline $\begin{array}{l}\text { Disk Narrowing } \\
\text { without } \\
\text { Proliferation }\end{array}$ & $\begin{array}{l}0 \\
1 \\
2 \\
3 \\
4 \\
5 \\
6\end{array}$ & $\begin{array}{c}8 \\
7 \\
2 \\
1 \\
1 \\
-\end{array}$ & $\begin{array}{r}10 \\
7 \\
2 \\
- \\
- \\
-\end{array}$ & $\begin{array}{r}15 \\
3 \\
1 \\
- \\
- \\
-\end{array}$ & $\begin{array}{r}16 \\
6 \\
5 \\
2 \\
1 \\
1\end{array}$ & $\begin{array}{r}22 \\
6 \\
2 \\
1 \\
- \\
-\end{array}$ & $\begin{array}{r}24 \\
13 \\
7 \\
3 \\
2 \\
1\end{array}$ & $\begin{array}{r}32 \\
13 \\
4 \\
1 \\
- \\
-\end{array}$ & $\begin{array}{r}37 \\
9 \\
3 \\
1 \\
- \\
-\end{array}$ & $\begin{array}{l}\mathbf{M}_{1} \\
\mathbf{M}_{2} \\
\mathbf{F} \\
\mathbf{M}_{1}+\mathbf{F} \\
\mathbf{M}_{2}+\mathbf{F}\end{array}$ & $\begin{array}{l}\sim .25 \\
<.03 \\
<.06 \\
<.02 \\
<.005\end{array}$ \\
\hline $\begin{array}{l}\text { Vertebral } \\
\text { Subluxation }\end{array}$ & $\begin{array}{l}0 \\
1 \\
2 \\
3 \\
4 \\
5 \\
6\end{array}$ & $\begin{array}{l}7 \\
4 \\
3 \\
2 \\
2 \\
1 \\
-\end{array}$ & $\begin{array}{l}7 \\
8 \\
1 \\
3 \\
- \\
-\end{array}$ & $\begin{array}{r}15 \\
2 \\
1 \\
1 \\
-\end{array}$ & $\begin{array}{r}14 \\
8 \\
6 \\
2 \\
1 \\
-\end{array}$ & $\begin{array}{r}21 \\
8 \\
1 \\
1 \\
- \\
-\end{array}$ & $\begin{array}{r}21 \\
12 \\
9 \\
4 \\
3 \\
1 \\
-\end{array}$ & $\begin{array}{r}28 \\
16 \\
1 \\
2 \\
3 \\
-\end{array}$ & $\begin{array}{r}36 \\
10 \\
2 \\
1 \\
1 \\
-\end{array}$ & $\begin{array}{l}\mathbf{M}_{1} \\
\mathbf{M}_{2} \\
\mathbf{F} \\
\mathbf{M}_{1}+\mathbf{F} \\
\mathbf{M}_{2}+\mathbf{F}\end{array}$ & $\begin{array}{l}\sim .60 \\
<.02 \\
<.02 \\
<.07 \\
<.002\end{array}$ \\
\hline $\begin{array}{l}\text { Apophyseal } \\
\text { Proliferation }\end{array}$ & $\begin{array}{l}0 \\
1 \\
2 \\
3 \\
4 \\
5 \\
6\end{array}$ & $\begin{array}{l}2 \\
2 \\
5 \\
3 \\
3 \\
3 \\
1 \\
\end{array}$ & $\begin{array}{l}- \\
2 \\
2 \\
6 \\
4 \\
4 \\
1\end{array}$ & & $\begin{array}{l}6 \\
8 \\
5 \\
7 \\
3 \\
2 \\
\end{array}$ & $\begin{array}{l}4 \\
5 \\
7 \\
5 \\
4 \\
3 \\
3 \\
\end{array}$ & $\begin{array}{r}8 \\
10 \\
10 \\
10 \\
6 \\
5 \\
1 \\
\end{array}$ & $\begin{array}{r}4 \\
7 \\
9 \\
11 \\
8 \\
7 \\
4 \\
\end{array}$ & & $\begin{array}{l}\mathbf{M}_{1} \\
\mathrm{~F} \\
\mathrm{M}_{1}+\mathrm{F}\end{array}$ & $\begin{array}{l}\sim .20 \\
\sim .15 \\
<.06 \\
\rightarrow\end{array}$ \\
\hline $\begin{array}{l}\text { Apophyseal } \\
\text { Destruction }\end{array}$ & $\begin{array}{l}0 \\
1 \\
2 \\
3 \\
4 \\
5 \\
6\end{array}$ & $\begin{array}{l}2 \\
8 \\
7 \\
1 \\
1 \\
-\end{array}$ & $\begin{array}{l}5 \\
6 \\
5 \\
2 \\
1 \\
- \\
-\end{array}$ & $\begin{array}{l}9 \\
6 \\
3 \\
1 \\
-\end{array}$ & $\begin{array}{l}6 \\
9 \\
8 \\
3 \\
3 \\
1 \\
1\end{array}$ & $\begin{array}{r}13 \\
13 \\
2 \\
3 \\
- \\
-\end{array}$ & $\begin{array}{r}8 \\
17 \\
15 \\
4 \\
3 \\
2 \\
1\end{array}$ & $\begin{array}{r}18 \\
19 \\
7 \\
5 \\
1 \\
- \\
-\end{array}$ & $\begin{array}{r}22 \\
19 \\
5 \\
3 \\
1 \\
-\end{array}$ & $\begin{array}{l}\mathbf{M}_{1} \\
\mathbf{M}_{2} \\
\mathbf{F} \\
\mathbf{M}_{1}+\mathrm{F} \\
\mathbf{M}_{2}+\mathrm{F}\end{array}$ & $\begin{array}{l}\sim .75 \\
<.05 \\
<.003 \\
<.01 \\
<.001\end{array}$ \\
\hline $\begin{array}{l}\text { Apophyseal } \\
\text { Destruction } \\
\text { without } \\
\text { Anterior Wear }\end{array}$ & $\begin{array}{l}0 \\
1 \\
2 \\
3 \\
4 \\
5 \\
6\end{array}$ & $\begin{array}{l}9 \\
8 \\
2 \\
- \\
- \\
-\end{array}$ & $\begin{array}{l}14 \\
5 \\
= \\
= \\
-\end{array}$ & $\begin{array}{l}16 \\
3 \\
- \\
= \\
=\end{array}$ & $\begin{array}{r}9 \\
13 \\
2 \\
6 \\
1 \\
- \\
-\end{array}$ & $\begin{array}{r}21 \\
8 \\
2 \\
= \\
= \\
=\end{array}$ & $\begin{array}{r}18 \\
21 \\
4 \\
6 \\
1 \\
-\end{array}$ & $\begin{array}{l}35 \\
13 \\
2 \\
= \\
= \\
-\end{array}$ & $\begin{array}{r}37 \\
11 \\
2 \\
- \\
- \\
-\end{array}$ & $\begin{array}{l}\mathbf{M}_{1} \\
\mathbf{M}_{2} \\
\mathbf{F} \\
\mathbf{M}_{1}+\mathbf{F} \\
\mathbf{M}_{2}+\mathbf{F}\end{array}$ & $\begin{array}{l}<.07 \\
<.02 \\
<.001 \\
<.0003 \\
<.0001\end{array}$ \\
\hline $\begin{array}{l}\text { Vertebral } \\
\text { Proliferation }\end{array}$ & $\begin{array}{l}0 \\
1 \\
2 \\
3 \\
4 \\
5 \\
6\end{array}$ & $\begin{array}{l}5 \\
1 \\
4 \\
3 \\
4 \\
2 \\
-\end{array}$ & $\begin{array}{l}3 \\
1 \\
3 \\
6 \\
3 \\
1 \\
2\end{array}$ & & $\begin{array}{r}9 \\
11 \\
4 \\
4 \\
2 \\
1 \\
\end{array}$ & $\begin{array}{l}9 \\
9 \\
3 \\
5 \\
5 \\
\\
\end{array}$ & $\begin{array}{r}14 \\
12 \\
8 \\
7 \\
6 \\
3 \\
\end{array}$ & $\begin{array}{r}12 \\
10 \\
6 \\
11 \\
8 \\
1 \\
2\end{array}$ & & $\begin{array}{l}\mathbf{M}_{1} \\
\mathbf{F} \\
\mathbf{M}_{1}+\mathbf{F}\end{array}$ & $\begin{array}{l}\sim .40 \\
\sim .50 \\
\sim \cdot 40 \\
\rightarrow\end{array}$ \\
\hline $\begin{array}{c}\text { Sclerosis of } \\
\text { Vertebral Plates }\end{array}$ & $\begin{array}{l}0 \\
1 \\
2 \\
3 \\
4 \\
5 \\
6\end{array}$ & $\begin{array}{r}11 \\
4 \\
4 \\
- \\
- \\
\end{array}$ & $\begin{array}{l}6 \\
6 \\
5 \\
1 \\
-\end{array}$ & & $\begin{array}{r}23 \\
5 \\
2 \\
1 \\
- \\
-\end{array}$ & $\begin{array}{r}16 \\
7 \\
6 \\
2 \\
- \\
-\end{array}$ & $\begin{array}{r}34 \\
9 \\
6 \\
1 \\
- \\
-\end{array}$ & $\begin{array}{r}22 \\
13 \\
11 \\
3 \\
-\end{array}$ & & $\begin{array}{l}\mathbf{M}_{1} \\
\mathbf{F} \\
\mathbf{M}_{1}+\mathbf{F}\end{array}$ & $\begin{array}{l}<.08 \\
<.05 \\
<.02 \\
\rightarrow\end{array}$ \\
\hline
\end{tabular}


TABLE I-continued

\begin{tabular}{|c|c|c|c|c|c|c|c|c|c|c|c|}
\hline \multirow{3}{*}{$\frac{\begin{array}{c}\text { Characteristic } \\
\text { Examined }\end{array}}{\text { All }}$} & \multirow{3}{*}{$\begin{array}{c}\begin{array}{c}\text { Weighted } \\
\text { Score }\end{array} \\
\text { Total }\end{array}$} & \multicolumn{3}{|c|}{ Male } & \multicolumn{2}{|c|}{ Female } & \multicolumn{3}{|c|}{ Male and Female } & \multirow{3}{*}{\multicolumn{2}{|c|}{$\begin{array}{c}\text { Probability of } \\
\text { Difference RA/Non-RA } \\
\text { More in RA } \\
\text { More in Non-RA }\end{array}$}} \\
\hline & & \multirow{2}{*}{$\begin{array}{l}(a) \\
19\end{array}$} & \multicolumn{2}{|c|}{$1^{(b)} 2$} & \multirow{2}{*}{$\frac{(a)}{31}$} & \multirow{2}{*}{ (b) } & \multirow{2}{*}{$\begin{array}{l}(a) \\
50\end{array}$} & \multicolumn{2}{|c|}{$1^{(b)} 2$} & & \\
\hline & & & 19 & 19 & & & & 50 & 50 & & \\
\hline $\begin{array}{c}\text { Anterior Wear } \\
\text { of Vertebral Plates }\end{array}$ & $\begin{array}{l}0 \\
1 \\
2 \\
3 \\
4 \\
5 \\
6\end{array}$ & $\begin{array}{r}4 \\
4 \\
4 \\
3 \\
2 \\
2 \\
-\end{array}$ & $\begin{array}{r}3 \\
2 \\
1 \\
3 \\
9 \\
1 \\
\end{array}$ & & $\begin{array}{r}13 \\
8 \\
6 \\
3 \\
1 \\
-\end{array}$ & $\begin{array}{r}6 \\
7 \\
9 \\
3 \\
6 \\
- \\
\end{array}$ & $\begin{array}{r}17 \\
12 \\
10 \\
6 \\
3 \\
2 \\
\end{array}$ & $\begin{array}{r}9 \\
9 \\
10 \\
6 \\
15 \\
1 \\
-\end{array}$ & & $\begin{array}{l}M_{1} \\
F \\
M_{1}+F\end{array}$ & $\begin{array}{l}<\cdot 10 \\
<\cdot 02 \\
<\cdot 01\end{array}$ \\
\hline $\begin{array}{l}\text { Osteoporosis } \\
\text { Lumbar Spine }\end{array}$ & $\begin{array}{l}0 \\
1 \\
2 \\
3 \\
4\end{array}$ & $\begin{array}{r}6 \\
8 \\
3 \\
2 \\
-\end{array}$ & $\begin{array}{l}9 \\
7 \\
3 \\
-\end{array}$ & & $\begin{array}{r}1 \\
8 \\
8 \\
13 \\
1\end{array}$ & $\begin{array}{r}13 \\
14 \\
3 \\
1 \\
\end{array}$ & $\begin{array}{r}7 \\
16 \\
11 \\
15 \\
1\end{array}$ & $\begin{array}{r}22 \\
21 \\
6 \\
1\end{array}$ & & $\begin{array}{l}\mathbf{M} \\
\mathbf{F} \\
\mathbf{M}+\mathbf{F}\end{array}$ & $\begin{array}{l}<\cdot 20 \\
<\cdot 000,001 \\
<\cdot 000,01\end{array}$ \\
\hline
\end{tabular}

the D12 disk, that between the 1st and 2nd lumbar vertebrae as the L1 disk and so on. In a few films the D12 disk was not visible and had to be excluded. There were two such in the rheumatoid group and three in the controls. All films were jointly read by two observers. A weighting by extent and severity was applied by adding the gradings of the individual disks together. As five disks were involved, the possible maximum count in this addition was twenty, but in fact the highest obtained was thirteen. For convenience of tabulation and statistical comparison Counts $\mathbf{0}$ and $\mathbf{1}$ were combined in Score $\mathbf{0}$, Counts 2 and 3 in Score 1, and so on up to Score 6 . The significance test applied is the comparison of mean scores described by Cochran (1954). A probability of $<.05$ was taken as the minimal level of significance.

In contrast to the cervical spine where, in the rheumatoid subjects, an excess of disk narrowing with little or no osteophytosis on the vertebral bodies was found in the upper disks, in the lumbar spine the distribution of narrowed disks was more uniform and disk narrowing was almost invariably associated with some degree of

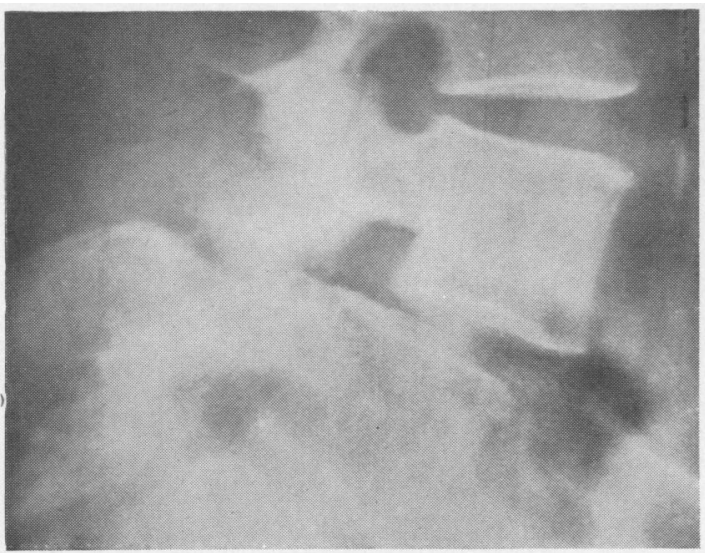

Fig. 1.-Anterior subluxation Grade 4 of 4 th lumbar vertebra in a female with rheumatoid arthritis. There would appear to be gross destruction of the upper facets on L5.

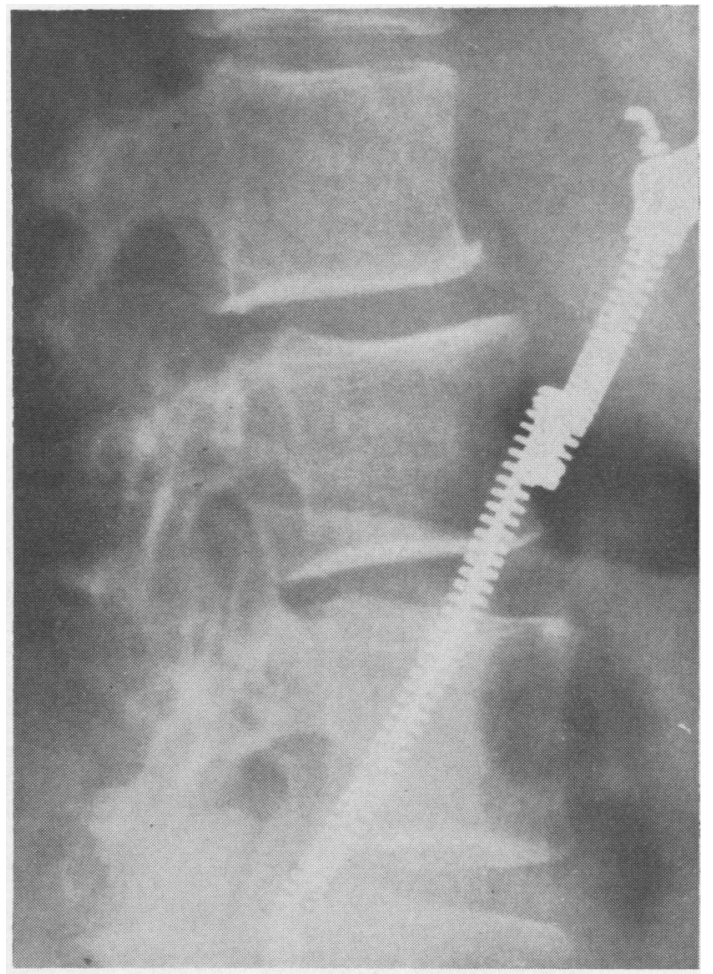

Fig. 2.-Posterior subluxation of 3rd and 4th lumbar vertebrae in a female with a positive SCAT. There is destruction and upward subluxation of the 4 th apophyseal joint. (Case 3, below).

vertebral proliferation. An attempt was therefore made to determine whether disk narrowing when it occurred was out of proportion to the degree of vertebral proliferation. Such narrowing was labelled "disk destruction". Other factors studied were subluxation (Figs 1 and 2), anterior wear of vertebral bodies (Fig. 3, overleaf), proliferation of vertebral bodies, sclerosis of vertebral plates, 


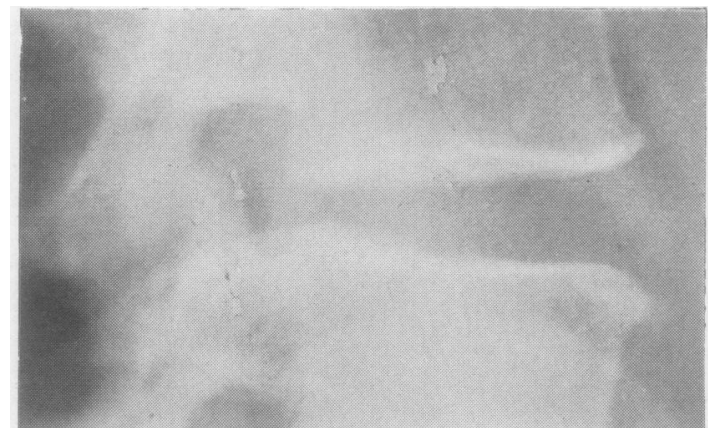

Fig. 3.-Anterior wear and osteophyte formation both Grade 2 in a non-rheumatoid subject.

proliferation and destructive changes in the apophyseal joints (Figs 4 and 5), osteoporosis, marginal bridging of disk spaces, and Schmorl's nodes.

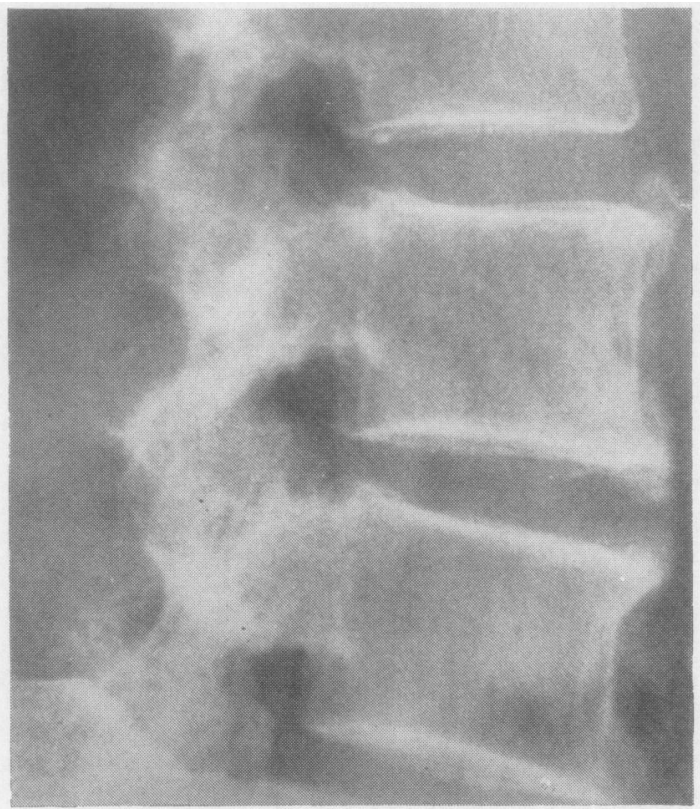

Fig. 4.-Proliferative changes on apophyseal joints and at disk margin in a non-rheumatoid subject.

\section{Results}

Disk narrowing tended to be more frequent in the rheumatoid subjects but the differences were not significant (Table I). When, however, only those disks in which narrowing was associated with little or no osteophytosis were considered, the difference was significant. In none of the spines in the nonrheumatoid group did disk narrowing without proliferation score more than 3 , whereas three spines in the rheumatoid group had scores of 5 and 6 .

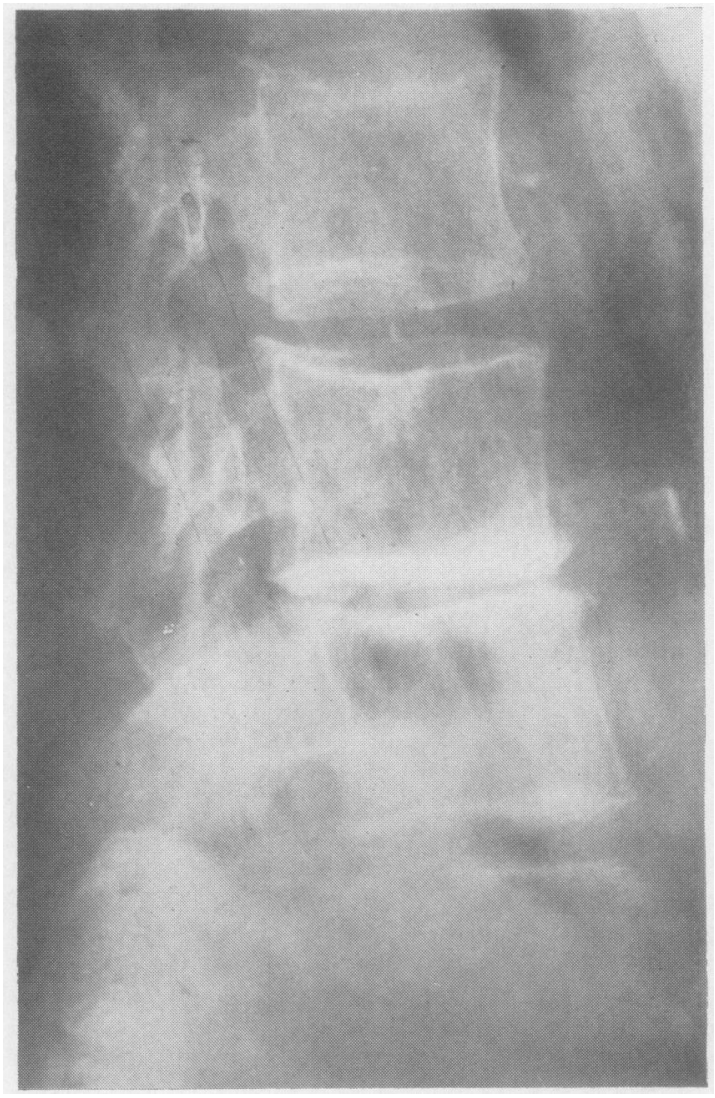

Fig. 5.-Grade 3 rheumatoid arthritis. Destructive changes in apophyseal joints in a female with positive SCAT. Despite marked narrowing of disk there is little osteophyte formation.

The difference is significant $(P<\cdot 02)$. When the miners were excluded the difference became greater $(\mathrm{P}<\cdot 005)$. The difference between 'rheumatoids' and controls was greater in males when the miners were excluded but was otherwise greater in females. The disk narrowing was more frequent in the rheumatoid group at all levels except L3 and was more severe at all levels except the $\mathrm{L} 1$ disk. It is of interest that L3 was the disk found to be most commonly affected by degenerative change in a group of miners, light manual workers and office workers studied earlier (Lawrence, 1955). The greatest difference between the rheumatoid and control group was encountered in the L4 disk which was also the disk most frequently showing narrowing without proliferation.

Vertebral subluxation was also more frequent in the rheumatoid group, but only in females. When, however, non-manual workers were substituted for the miners, the difference was just as significant in 
males as in females $(P<\cdot 02)$. Vertebral subluxation was more frequent at all levels of the lumbar spine in the rheumatoid group, the excess being mostly of mild degree but also including the only severe subluxation in the sample. Moderate subluxation, however, was common in non-rheumatoid males in association with evidence of disk degeneration. The subluxation was in a forward direction in four of the rheumatoid group including the one case of severe subluxation. None of the nonrheumatoid group had anterior subluxation. Backward subluxation was found in both groups. In both rheumatoid and non-rheumatoid subjects there was narrowing of the disk at the level of subluxation in just over half (55 and 57 per cent. respectively). Subluxation occurred more commonly below than above a narrow disk. It occurred most frequently at the L3 disk in the rheumatoid group, and at L2 in the controls. The D12 disk showed subluxation least often in both groups. Subluxation occurred in more than one disk in twelve rheumatoids and six controls.

Osteophyte formation at the disk margin (vertebral proliferation) was slightly more frequent in the controls but the difference was not significant. Both anterior wear of the vertebral bodies and sclerosis of the vertebral plates were significantly more frequent in the controls. Thus, apart from disk narrowing and subluxation, all those radiological signs commonly associated with disk degeneration were diminished in rheumatoid subjects.

The same conclusions may be drawn from the apophyseal joints. Destructive changes were more frequent in the rheumatoid group, proliferative changes in the controls. Destructive changes encountered were chiefly erosions of bone, as it was seldom possible to give an opinion on joint space from the lateral film. Minimal erosions of bone, however, were difficult to detect and it was sometimes impossible to differentiate them from an early osteophyte fringe. This may account for our finding that only severe erosions were more frequent in the rheumatoid group and that in males, as long as the miners were included in the non-rheumatoid arthritis group, there was a very poor correlation between apophyseal destruction and rheumatoid arthritis. The most severe destruction was encountered in the presence of anterior subluxation when the lower facets might be almost completely eroded away (Fig. 1, above, p. 207).

Apophyseal destruction in the absence of anterior wear was still more characteristic for the rheumatoid group.

There was a very significant association between osteoporosis and rheumatoid arthritis in females.
Schmorl's nodes were equally distributed between the rheumatoid and non-rheumatoid groups. They often had a less defined margin in the rheumatoid group but were otherwise identical. Marginal bridging of disk spaces was encountered in five rheumatoid and six non-rheumatoid subjects. It was of the type described by Forestier and RotesQuérol (1950) in senile ankylosing hyperostosis.

\section{Assessment of Frequency in Population and Relation- ship to the SCAT}

In the blind reading of $x$ rays from population samples, the features shown to be more common in the rheumatoid and sero-positive persons, such as subluxation, particularly if multiple, and disk narrowing without a corresponding degree of proliferation, sclerosis, or anterior wear, were considered the main criteria for a definite grading of rheumatoid arthritis. Subluxation at a degenerate disk unless in a forward direction was considered to provide only doubtful evidence. Destructive changes in the facets unless very definite were thought insufficient for a clear diagnosis. Minimal erosions, however, were considered to support the diagnosis and to raise the grading if other features were present. Similarly, osteoporosis was regarded as supporting the diagnosis but not as in itself diagnostic. Marked proliferation or sclerotic changes were considered to counter a diagnosis of rheumatoid arthritis and resulted in a lower grading where other signs of arthritis were present. The $x$ rays used as standards for Grade 3 and 2 are shown in Fig. 5 (see p. 208) and Fig. 6 (overleaf, p. 210).

Lumbar radiographs were available for 438 persons aged 55 to 64 in the Leigh and Vale of Glamorgan surveys and, of these, 413 had a SCAT. Since, in the Vale of Glamorgan, only the females had lumbar spine $x$ rays, there were 153 males and 260 females in the sample used. All films were read by two observers independently, the gradings of these two observers being added together and divided by two. The maximum score for rheumatoid arthritis awarded by either observer was 3 , so that there were seven possible grades, $0, \frac{1}{2}, 1,1 \frac{1}{2}$, up to 3 .

Observer Difference.-A comparison of the grading of 100 selected lumbar $x$ rays by two observers showed a positive correlation between their gradings $(r=+\cdot 62)$. Though this correlation may be regarded as only moderate, its difference from zero is highly significant (six times the standard error).

When one observer read the same films subsequently the correlation was only slightly better $(r=+\cdot 69)$, but when the same observer read the films a third time a greater degree of conformity 


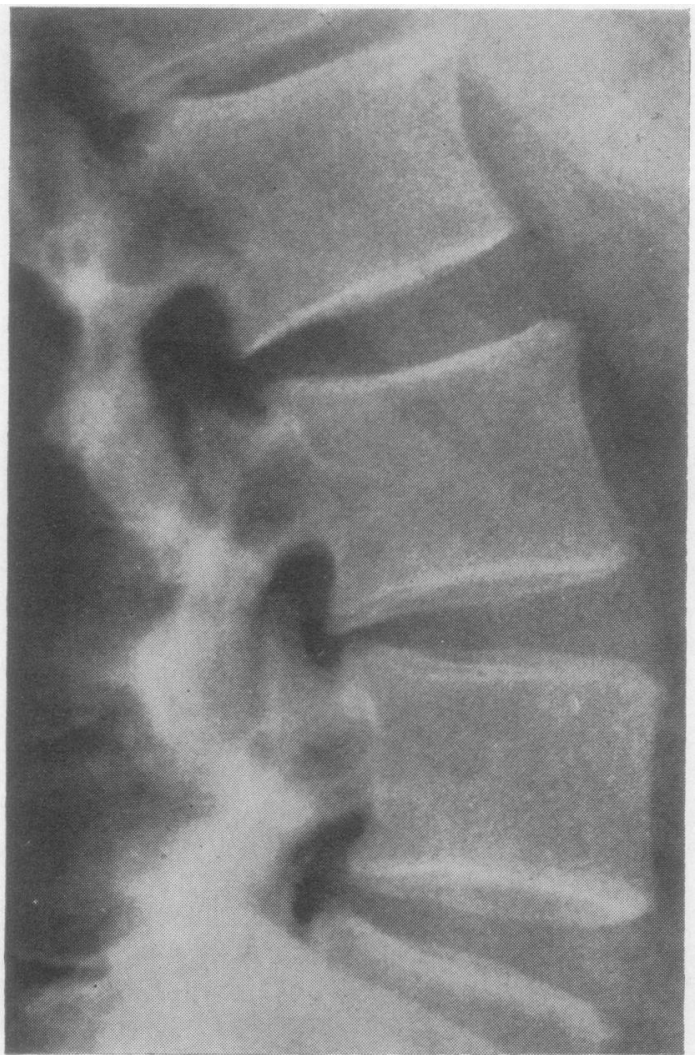

Fig. 6.-Grade 2 rheumatoid arthritis. Erosions L2 apophyseal joints, with slight posterior subluxation at $\mathrm{L} 3$ and anterior subluxation at L4. Posterior narrowing L3 disk. (Case 1).

between the second and third readings was obtained $(r=+\cdot 81)$.

\section{Prevalence of "Lumbar Rheumatoid Arthritis"}

When the total sample was assessed, the prevalence of rheumatoid arthritis in the lumbar spine (Grade 2-3) was found to be 5 per cent. in males and 3 per cent. in females (Table II). This may be compared with the figures of 6 and 7 per cent. for cervical rheumatoid arthritis in this age group in the Leigh and Glamorgan population samples. The difference is not accounted for by the fact that among the 22 individuals in whom the cervical but no lumbar films were available there were six with other evidence of rheumatoid disease, since only two of these six had cervical arthritis. It must be concluded that arthritis is less frequent in the lumbar spine, is more difficult to recognize, or both. The difference in prevalence between males and females is not significant.

There was a significant association with the SCAT, which was positive at a titre of $1: 32$ or higher, in 18 per cent of those with Grade 2-3 rheumatoid arthritis and in 8 per cent. of those with Grade $1-1 \frac{1}{2}$, but in only 4 per cent. of those with Grade $0-\frac{1}{2}$ arthritis $(\mathrm{P}<\cdot 03)$. The association was present in both sexes though more striking in males.

\section{Relationship of "Lumbar Rheumatoid Arthritis" to Other Evidence of Rheumatoid Arthritis}

The lumbar rheumatoid grading showed some relationship to radiological signs of erosive arthritis in the hands and feet but only in the sero-positive group was this at all striking (Table III, opposite).

All three subjects with Grade 2-3 lumbar rheumatoid arthritis in the sero-positive group had erosions in the hands or feet, whereas only two of thirteen sero-positive individuals with no lumbar arthritis had hand or foot erosions. The four with doubtful lumbar change occupied an intermediate position, only one having erosions in the peripheral joints. In the sero-negative group, the proportion with peripheral erosions rose only from 5 to 7 per cent. with increasing severity of lumbar arthritis.

Similarly, there was an association of lumbar with cervical arthritis in the sero-positive group, but not in those with a negative SCAT (Table IV, opposite).

Of three with definite lumbar arthritis in the seropositive group, two had cervical involvement, but

TABLE II

SCAT RESULTS AND $X$-RAY CHANGES OF "LUMBAR RA"

\begin{tabular}{|c|c|c|c|c|c|c|c|c|c|c|}
\hline \multirow{3}{*}{ SCAT Results } & \multirow{3}{*}{ Total } & \multicolumn{9}{|c|}{ Grade of "Lumbar RA" } \\
\hline & & \multicolumn{3}{|c|}{ Male and Female } & \multicolumn{3}{|c|}{ Male } & \multicolumn{3}{|c|}{ Female } \\
\hline & & $0-\frac{1}{2}$ & $1-1 \frac{1}{2}$ & $2-3$ & $0-\frac{1}{2}$ & $1-1 \frac{1}{2}$ & $2-3$ & $0-\frac{1}{2}$ & $1-1 \frac{1}{2}$ & $2-3$ \\
\hline $\begin{array}{l}\text { Negative } \\
\text { Positive }\end{array}$ & $\begin{array}{r}393 \\
20\end{array}$ & $\begin{array}{r}330 \\
13\end{array}$ & $\begin{array}{r}49 \\
4\end{array}$ & $\begin{array}{r}14 \\
3\end{array}$ & $\begin{array}{r}115 \\
5\end{array}$ & $\begin{array}{r}24 \\
1\end{array}$ & $\begin{array}{l}6 \\
2\end{array}$ & $\begin{array}{c}215 \\
8\end{array}$ & $\begin{array}{r}25 \\
3\end{array}$ & $\begin{array}{l}8 \\
1\end{array}$ \\
\hline Total & 413 & 343 & 53 & $17(4 \%)$ & 120 & 25 & $8(5 \%)$ & 223 & 28 & $9(3 \%)$ \\
\hline Positive per cent. & 5 & 4 & 8 & 18 & 4 & 4 & 25 & 4 & 11 & 11 \\
\hline
\end{tabular}


TABLE III

$X$-RAY CHANGES OF "LUMBAR RA" AND OF ARTHRITIS IN HANDS AND/OR FEET

\begin{tabular}{|c|c|c|c|c|c|c|c|c|}
\hline \multirow{3}{*}{$\begin{array}{l}\text { Grade of Arthritis } \\
\text { in Hands and/or Feet }\end{array}$} & \multicolumn{8}{|c|}{ Grade of "Lumbar RA" } \\
\hline & \multicolumn{4}{|c|}{ SCAT Negative } & \multicolumn{4}{|c|}{ SCAT Positive } \\
\hline & Total & $0-\frac{1}{2}$ & $1-1 \frac{1}{2}$ & $2-3$ & Total & $0-\frac{1}{2}$ & $1-1 \frac{1}{2}$ & $2-3$ \\
\hline $\begin{array}{l}0 \\
1 \\
2 \\
3 \\
4\end{array}$ & $\begin{array}{r}231 \\
141 \\
19 \\
0 \\
2\end{array}$ & $\begin{array}{r}199 \\
114 \\
15 \\
0 \\
2\end{array}$ & $\begin{array}{r}25 \\
21 \\
3 \\
0 \\
0\end{array}$ & $\begin{array}{l}7 \\
6 \\
1 \\
0 \\
0\end{array}$ & $\begin{array}{l}8 \\
6 \\
3 \\
1 \\
2\end{array}$ & $\begin{array}{l}7 \\
4 \\
2 \\
0 \\
0\end{array}$ & $\begin{array}{l}1 \\
2 \\
0 \\
1 \\
0\end{array}$ & $\begin{array}{l}0 \\
0 \\
1 \\
0 \\
2\end{array}$ \\
\hline Total No. & 393 & 330 & 49 & 14 & 20 & 13 & 4 & 3 \\
\hline Grade 2-4 per cent & 5 & 5 & 6 & 7 & 30 & 15 & 25 & 100 \\
\hline
\end{tabular}

No lumbar films available of four Hands and/or Feet Grade 2-4, SCAT Negative, and two Hands and/or Feet Grade 2-4, SCAT Positive

TABLE IV

$X$-RAY CHANGES OF "LUMBAR RA" AND OF "CERVICAL RA"

\begin{tabular}{|c|c|c|c|c|c|c|c|c|}
\hline \multirow{3}{*}{$\begin{array}{l}\text { Grade of } \\
\text { "Cervical RA" }\end{array}$} & \multicolumn{8}{|c|}{ Grade of "Lumbar RA" } \\
\hline & \multicolumn{4}{|c|}{ SCAT Negative } & \multicolumn{4}{|c|}{ SCAT Positive } \\
\hline & Total & $0-\frac{1}{2}$ & $1-1 \frac{1}{2}$ & $2-3$ & Total & $0-\frac{1}{2}$ & $1-1 \frac{1}{2}$ & $2-3$ \\
\hline $\begin{array}{l}0 \\
1 \\
2 \\
3\end{array}$ & $\begin{array}{r}282 \\
87 \\
23 \\
1\end{array}$ & $\begin{array}{r}238 \\
71 \\
20 \\
1\end{array}$ & $\begin{array}{r}36 \\
11 \\
2 \\
0\end{array}$ & $\begin{array}{l}8 \\
5 \\
1 \\
0\end{array}$ & $\begin{array}{l}9 \\
7 \\
3 \\
1\end{array}$ & $\begin{array}{l}6 \\
6 \\
1 \\
0\end{array}$ & $\begin{array}{l}2 \\
1 \\
0 \\
1\end{array}$ & $\begin{array}{l}1 \\
0 \\
2 \\
0\end{array}$ \\
\hline Total No. & 393 & 330 & 49 & 14 & 20 & 13 & 4 & 3 \\
\hline Grade $2-3$ per cent. & 6 & 6 & 4 & 7 & 20 & 8 & 25 & 67 \\
\hline
\end{tabular}

No lumbar films available of one Cervical Grade 2-3, SCAT Negative, and one Cervical Grade 2-3, SCAT Positive

only one of the four with doubtful disease and one of the thirteen with no disease. In the sero-negative group the prevalence of cervical involvement rose only from 6 to 7 per cent. with increasing severity of the lumbar change. No association was observed between sacro-iliitis and lumbar arthritis (Table V).

TABLE V

RELATIONSHIP OF SACRO-ILIITIS TO LUMBAR RHEUMATOID ARTHRITIS

\begin{tabular}{|c|c|c|c|c|c|c|c|c|}
\hline \multirow{3}{*}{$\begin{array}{l}\text { Grade of } \\
\text { Sacro-Iliitis }\end{array}$} & \multicolumn{8}{|c|}{ Grade of "Lumbar RA" (combined reading) } \\
\hline & \multicolumn{4}{|c|}{ SCAT Negative } & \multicolumn{4}{|c|}{ SCAT Positive } \\
\hline & Total & $0-\frac{1}{2}$ & $1-1 \frac{1}{2}$ & $2-3$ & Total & $0-\frac{1}{1}$ & $1-1 \frac{1}{2}$ & $2-3$ \\
\hline $\begin{array}{c}0 \\
1 \\
2 \\
3 \text { and } 4 \\
\text { Not Stated }\end{array}$ & $\begin{array}{r}268 \\
94 \\
14 \\
1 \\
16\end{array}$ & $\begin{array}{r}218 \\
83 \\
13 \\
1 \\
15\end{array}$ & $\begin{array}{r}39 \\
9 \\
1 \\
0 \\
0\end{array}$ & $\begin{array}{r}11 \\
2 \\
0 \\
0 \\
1\end{array}$ & $\begin{array}{r}11 \\
4 \\
3 \\
0 \\
2\end{array}$ & $\begin{array}{l}6 \\
3 \\
2 \\
0 \\
2\end{array}$ & $\begin{array}{l}3 \\
1 \\
0 \\
0 \\
0\end{array}$ & $\begin{array}{l}2 \\
0 \\
1 \\
0 \\
0\end{array}$ \\
\hline Total No. & 393 & 330 & 49 & 14 & 20 & 13 & 4 & 3 \\
\hline Grade 2-4 per cent. & 4 & 4 & 2 & $\mathbf{0}$ & 17 & 18 & & \\
\hline
\end{tabular}


The association between clinical polyarthritis and lumbar change was less convincing (Table VI). Two of the three sero-positive individuals with definite lumbar arthritis had clinical disease but so had four of the thirteen with no lumbar change. In the seronegative group there was no association.

When all sites of $x$-ray changes were considered (Table VII), it was found that among the 23 individuals in whom the hands or feet were affected without the lumbar spine, three (13 per cent.) had a positive SCAT, whereas three of the four with both peripheral and lumbar joint involvement were seropositive. Those with only the lumbar spine involved were all sero-negative. Two of the 21 in whom the hands or feet were affected, but not the lumbar or cervical spine, had a positive SCAT. Only one of the 36 without hand or foot involvement but with either cervical or lumbar affection was sero-positive whereas four out of six with hands or feet involved, and the cervical or lumbar spine in addition, were sero-positive. Of twenty with a positive SCAT and a complete set of $x$ rays in this population sample, thirteen had no erosive arthritis, four had both peripheral and spinal involvement, one had only the neck affected, and two only the peripheral joints.

\section{Relationship to Symptoms}

Symptoms in the lumbar region and in the areas of reference of pain from the lumbar spine classified according to the system of Kellgren $(1939,1940)$ and Lewis (1942) are of considerable frequency in the population and are a common source of incapacity, particularly in those engaged in heavy manual work. Coal-miners, who were the largest occupational group in Leigh, are particularly prone to incapacity from this cause. This appears to be due to the high prevalence of disk degeneration in such workers (Kellgren and Lawrence, 1952). As a result this population group is not ideally suited to a study of symptoms due to arthritis. There were in fact complaints of lumbar (D12-L2) pain in 41 per cent. of those with Grade $0-\frac{1}{2}$ lumbar rheumatoid arthritis

TABLE VI

$X$-RAY CHANGES OF "LUMBAR RA" AND CLINICAL POLYARTHRITIS

\begin{tabular}{|c|c|c|c|c|c|c|c|c|}
\hline \multirow{3}{*}{$\begin{array}{l}\text { Grade of Clinical } \\
\text { Polyarthritis }\end{array}$} & \multicolumn{8}{|c|}{ Grade of "Lumbar RA" } \\
\hline & \multicolumn{4}{|c|}{ SCAT Negative } & \multicolumn{4}{|c|}{ SCAT Positive } \\
\hline & Total & $0-\frac{1}{2}$ & $1-1 \frac{1}{2}$ & $2-3$ & Total & $0-\frac{1}{2}$ & $1-1 \frac{1}{2}$ & $2-3$ \\
\hline $\begin{array}{l}0 \\
1 \\
2 \\
3 \\
4\end{array}$ & $\begin{array}{r}331 \\
30 \\
26 \\
3 \\
3\end{array}$ & $\begin{array}{r}275 \\
26 \\
25 \\
2 \\
2\end{array}$ & $\begin{array}{r}44 \\
3 \\
0 \\
1 \\
1\end{array}$ & $\begin{array}{r}12 \\
1 \\
1 \\
0 \\
0\end{array}$ & $\begin{array}{r}12 \\
1 \\
3 \\
1 \\
3\end{array}$ & $\begin{array}{l}8 \\
1 \\
3 \\
1 \\
0\end{array}$ & $\begin{array}{l}3 \\
0 \\
0 \\
0 \\
1\end{array}$ & $\begin{array}{l}1 \\
0 \\
0 \\
0 \\
2\end{array}$ \\
\hline Total No. & 393 & 330 & 49 & 14 & 20 & 13 & 4 & 3 \\
\hline Grade $2-4$ per cent. & 8 & 9 & 4 & 7 & 35 & 31 & 25 & 67 \\
\hline
\end{tabular}

No lumbar films available of two Clin. PA Grade 2-4, SCAT Positive, and one Clin. PA Grade 2-4, SCAT Positive.

TABLE VII

RADIOLOGICAL RA AT VARIOUS SITES AND POSITIVE SCAT RESULTS

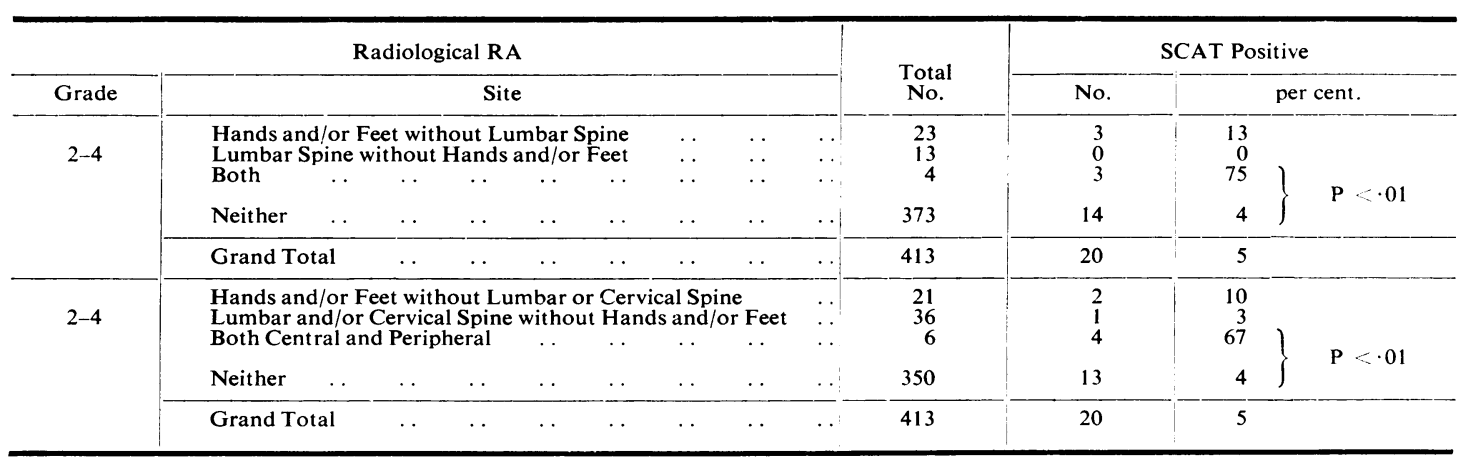


and in 44 per cent. of those with Grade $1-1 \frac{1}{2}$ changes (Table VIII). Of those with definite changes 53 per cent complained of lumbar pain. Pain in the L3-4 distribution (anterior and lateral surface of the thighs) was not more frequent in those with radiological lumbar rheumatoid arthritis, but L5-S2 pain (outer side and back of leg) was three times as frequent in these subjects, the difference between Grades $0-\frac{1}{2}$ and $1-3$ in this respect being significant $(P<\cdot 03)$. Recurrent attacks of pain and incapacitating pain were more common in those with radiological lumbar arthritis, but chronic pain, single attacks, and mild symptoms without loss of work were just as common in those without evidence of rheumatoid arthritis. Details of the sex distribution are not given in Table VIII because of the small numbers with definite radiological disease. It may be of interest that the association between radiological lumbar rheumatoid arthritis and L5-S2 pain was rather greater in males.

\section{Illustrative Cases}

Case 1, a man aged 65, stated that 20 years previously his hands became stiff, then his knees. These symptoms have persisted ever since. During the first 2 years he was able to continue his work as a miner but the symptoms then became so severe that he was unable to work for 4 years. He has since had occasional periods of incapacity: 12 years ago he was moving a powder box, when he happened to sneeze; he felt a severe pain at the bottom of his back and had to go to bed for a month not daring to move; thereafter the pain eased but he could not move his legs which felt numb, the legs gradually recovered and he returned to work after 15 weeks. A second attack occurred several years later when swabbing the floor, but the legs were unaffected; he was only in bed for a week or two, and off work for a month. He has had no back trouble since but the hands and knees have remained stiff and he has had pain in his elbows, shoulders, neck and feet.

Examination.-There were characteristic changes of rheumatoid arthritis in the proximal interphalangeal and metacarpo-phalangeal joints and wrists with swelling and subluxation. The elbows were grossly limited as were the joints of the feet. There was limitation of lateral bending and rotation of the cervical spine and of all movements of the dorso-lumbar spine. Subcutaneous and tendon nodules were present.

Radiographs.-The hands and feet showed gross erosive changes in the metacarpo-phalangeal and metatarso-phalangeal joints. In the lumbar spine there was anterior subluxation of the 4th lumbar vertebra with erosion of the facets. The 5th lumbar apophyseal joint appeared to be ankylosed. There was posterior subluxation of the 1st, 2nd, and 3rd lumbar vertebrae with narrowing of the 1st and 3rd disks (Fig. 6, above, p. 210). The cervical spine showed only slight subluxation of $\mathrm{C} 2$ and 4.

SCAT.-Positive at a titre of $1: 128$ to $1: 512$ on various occasions.

Case 2, a woman aged 66, had pain and swelling in the hands, feet and knees 6 years before admission to Hammersmith Hospital, under the care of Prof. Bywaters; 4 years later she developed a peptic ulcer whilst under treatment with steroids and at about the same time a pleural effusion. When first seen 1 year ago she was almost completely crippled and could only sit in a chair. She had severe low back pain.

Examination.-She had classical rheumatoid arthritis of moderate severity affecting wrists, metacarpo-phalangeal joints, knees and metatarso-phalangeal joints. There was pain on movement of the spine with limitation of flexion. Both ankle jerks were sluggish and there was impaired sensation to pin-prick on the left leg of indefinite distribution. With physiotherapy she improved but still had persistent aching in the back and knees.

TABLE VIII

SEGMENTAL PAIN IN LUMBAR AREA AND LEG IN RELATION TO EROSIVE ARTHRITIS IN THE LUMBAR SPINE (438 SUBJECTS)

\begin{tabular}{|c|c|c|c|c|c|c|c|c|c|}
\hline \multirow{3}{*}{\multicolumn{4}{|c|}{$\begin{array}{l}\text { Segmental Distribution } \\
\text { and Severity of Pain }\end{array}$}} & \multicolumn{6}{|c|}{ Grade of "Lumbar RA" } \\
\hline & & & & \multicolumn{2}{|c|}{$0-\frac{1}{2}$} & \multicolumn{2}{|c|}{$1-1 \frac{1}{2}$} & \multicolumn{2}{|c|}{$2-3$} \\
\hline & & & & No. & per cent. & No. & per cent. & No. & per cent. \\
\hline Total No. of Subjects & $\ldots$ & $\ldots$ & $\ldots$ & 367 & 100 & 54 & 100 & 17 & 100 \\
\hline \multirow{3}{*}{ Subjects with Pain } & $\begin{array}{ll}\text { D12-L2 } & \ldots \\
\text { L3-L4 } & \ldots \\
\text { L5-S2 } & \\
\text { Total D12-S2 }\end{array}$ & $\begin{array}{l}\cdots \\
\cdots \\
\cdots\end{array}$ & $\begin{array}{l}\cdots \\
\cdots \\
\cdots\end{array}$ & $\begin{array}{r}149 \\
48 \\
36 \\
183\end{array}$ & $\begin{array}{l}41 \\
13 \\
10 \\
50\end{array}$ & $\begin{array}{l}24 \\
12 \\
12 \\
29\end{array}$ & $\begin{array}{l}44 \\
22 \\
22 \\
54\end{array}$ & $\begin{array}{r}9 \\
1 \\
5 \\
12\end{array}$ & $\begin{array}{r}53 \\
6 \\
29 \\
71\end{array}$ \\
\hline & $\begin{array}{l}\text { Single } \ldots \\
\text { Recurrent } \\
\text { Chronic ... }\end{array}$ & $\begin{array}{l}\cdots \\
\cdots \\
\cdots\end{array}$ & $\begin{array}{l}. . \\
\cdots\end{array}$ & $\begin{array}{l}54 \\
83 \\
46\end{array}$ & $\begin{array}{l}15 \\
23 \\
13\end{array}$ & $\begin{array}{r}10 \\
16 \\
7\end{array}$ & $\begin{array}{l}19 \\
30 \\
13\end{array}$ & $\begin{array}{l}3 \\
8 \\
2\end{array}$ & $\begin{array}{l}18 \\
47 \\
12\end{array}$ \\
\hline & \multicolumn{3}{|c|}{$\begin{array}{l}\text { Not losing work } \\
\text { Losing work } 1 \text { wk }+ \\
\text { Losing work } 3 \text { mths }+\ldots\end{array}$} & $\begin{array}{l}91 \\
92 \\
32\end{array}$ & $\begin{array}{r}25 \\
25 \\
9\end{array}$ & $\begin{array}{r}10 \\
19 \\
8\end{array}$ & $\begin{array}{l}19 \\
35 \\
15\end{array}$ & $\begin{array}{l}5 \\
7 \\
5\end{array}$ & $\begin{array}{l}29 \\
41 \\
29\end{array}$ \\
\hline
\end{tabular}




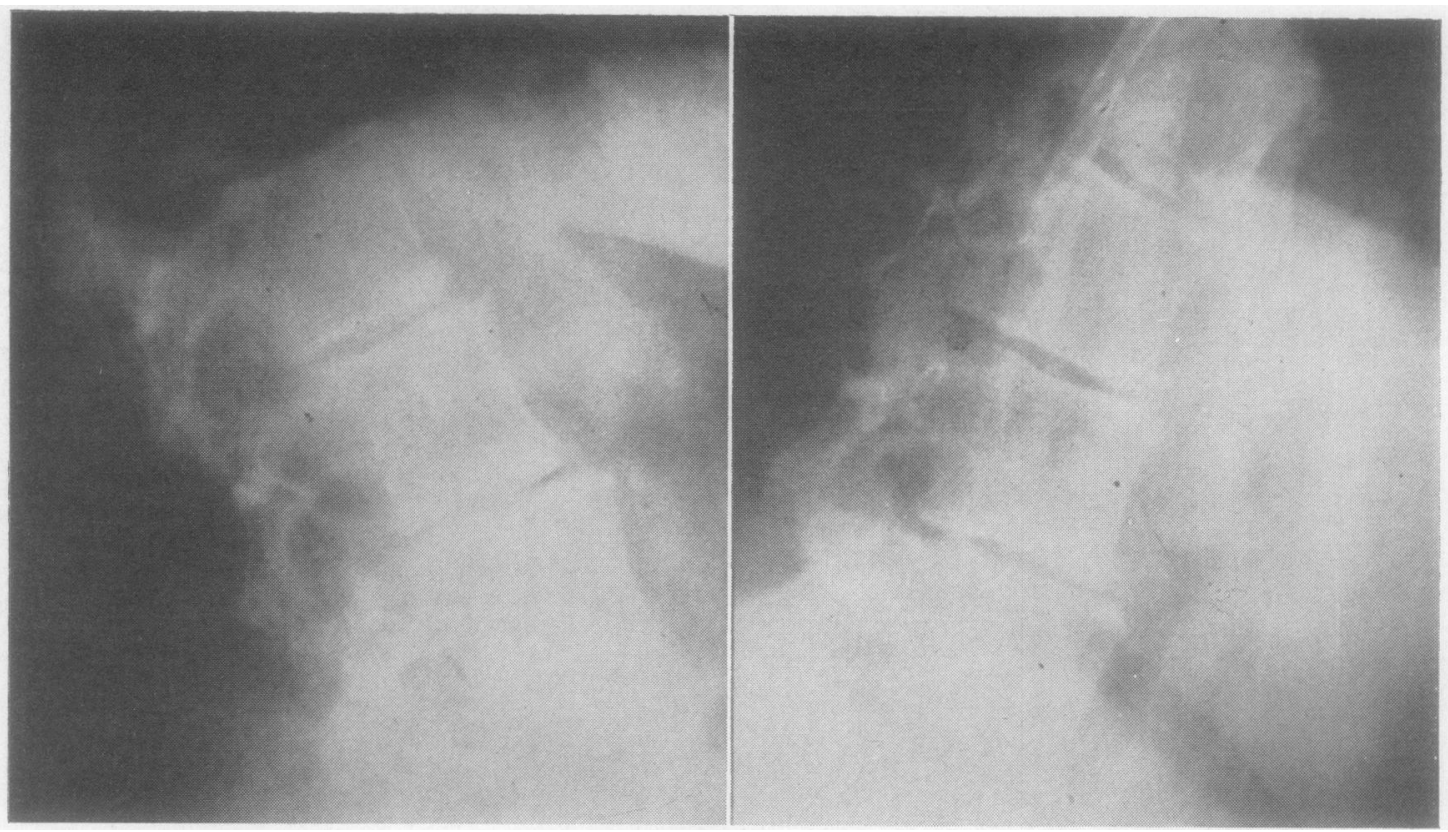

Fig. 7.-Case 2. Rheumatoid arthritis, erosions L2 apophyseal joints, and posterior subluxation at L1, 2, and 3 with narrowing of disks.

Radiographs.-The lumbar spine showed narrowing of the 1st, 2nd, and 3rd lumbar disks with posterior subluxation at the 2nd and 3rd (Fig. 7). In the cervical spine there was narrowing of all disks with anterior subluxation at $\mathrm{C} 4$ and 7 and posterior subluxation at $\mathrm{C5}$. Osteophyte formation was present at $\mathrm{C} 4$ and 7 apophyseal joints.

SCAT.-Positive at a titre of $1: 64$.

Latex-fixation Test.-Positive.

Erythrocyte Sedimentation Rate. $-40-60 \mathrm{~mm}$. in 1 hour.

The patient was given a corset which gave her great relief, and she has since continued to wear it; if she leaves it off the pain becomes worse.

Case 3, a woman aged 60, gave a 5-year history of pain in the tarsal region, especially in the left foot and latterly had pain in the low back and in the D10 segmental distribution, and pain and stiffness of the left elbow.

Examination.-There was pain on rotation of the dorso-lumbar spine and on all movements of the cervical spine. There was pain on all movements of the left ankle and tarsus, and limitation of the right tarsus.

Radiographs.-The lumbar spine (Fig. 2, above, p. 207) showed posterior subluxation of the 1 st and 2 nd lumbar vertebrae with posterior narrowing of the 3rd lumbar disk space and anterior osteophytes on the 1st vertebral body.

In the cervical spine there was narrowing of disks $\mathrm{C2}, 4$, 5 , and 6 with anterior subluxation of $\mathrm{C} 2$ and posterior subluxation of C5. The hands and feet showed slight osteo-arthrosis.

\section{$S C A T$._-Positive at a titre of $1: 32$.}

Case 4, a 72-year-old widow, had suffered from severe nodular rheumatoid arthritis for 17 years. For the last 4 of these she had received corticosteroid therapy with good relief of symptoms and had retained her independence but had developed multiple stress fractures in the lower limbs from severe osteoporosis.

Examination.-She had no back pain or sciatica, and an almost full and painless range of motion of the lumbar spine; straight leg raising was to $90^{\circ}$ on each side. The reflexes, power and sensation in the lower limbs were normal

Radiographs.-The lumbar spine (Fig. 8, opposite) showed marked narrowing of the L4 disk space with anterior subluxation. There was downward subluxation at the L4 apophyseal joint with diminished joint space.

\section{Autopsy Studies}

We have so far studied four lumbar spines removed at autopsy from patients with rheumatoid arthritis.

Case 5, a man aged 28, had had flitting joint pains 3 years before admission. After 9 months the fingers became permanently swollen and stiff and gradually the knees, ankles, elbows and metatarso-phalangeal joints became involved and also the shoulders. The patient died at age 34 of honeycomb lung. 


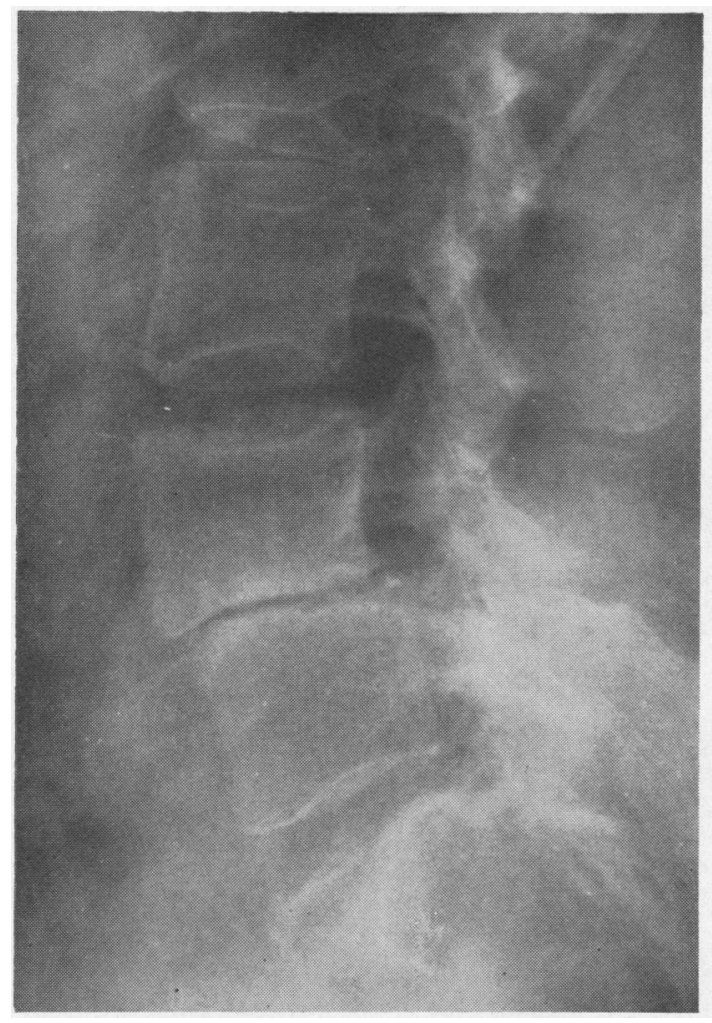

Fig. 8.-Case 4. Rheumatoid arthritis, anterior subluxation of L4 with erosion at apophyseal joints, and narrowing of L4 disk with sclerosis of vertebral plates.

Radiographs (taken before death).-The lumbar spine showed only slight posterior subluxation at two disks. The hands and feet showed osteoporosis, cartilage destruction, and marked erosion of articular bone.

Histology.-There were minor rheumatoid changes in the apophyseal joints but complete section of the disks in the horizontal plane showed no lesion.

Case 6, a woman aged 53, gave a history that her right index finger had become stiff and swollen after an injury 2 years previously; 6 months later the knee swelled and then the feet and hands and the symptoms became generalized.

Examination.-There was soft tissue swelling and effusion with limitation of the joints of the hands, elbows, shoulders, hips, knees and feet. The cervical spine was also affected and there was dorsal kyphosis and general limitation of the spine. The lumbar spine was not radiographed. The SCAT was negative. One year later she developed bilateral pulmonary tuberculosis, went rapidly downhill, and died.

Autopsy.-The lumbar spine showed early rheumatoid arthritis in the apophyseal joints, but this did not show on a slab $x$ ray. The disks were not sectioned.
Case 7, a woman aged 61 years, was admitted with a 14-year history of severe generalized polyarthritis. After 10 years she had become dyspnoeic and had two blood transfusions. Later fever, vomiting, and diarrhoea developed, and she was diagnosed as suffering from systemic lupus erythematosus though no L.E.-cells were found. A year later her condition deteriorated and she died of pulmonary embolism. The lumbar spine was not $x$ rayed during life but disk narrowing with marked sclerosis and osteophyte formation was visible on the barium enema films.

Autopsy. $-X$ rays showed narrowing of the 3rd lumbar disk with slight posterior subluxation, anterior wear and osteophyte formation, and a Schmorl's node was present in the adjacent vertebral body.

Histology.-There were degenerative changes in the 3rd lumbar disk and osteo-arthrosis in the apophyseal joints.

Case 8, a woman aged 61 years, gave a 12-year history of polyarthritis, initially affecting her hands, feet, knees and elbows. She was treated with gold and then with prednisolone and by 1960 had become clinically hypercorticoid with swelling of the limbs and general weakness. No $x$ rays were taken of the lumbar spine but there was arthritis in the cervical spine with gross atlanto-axial subluxation. She died shortly after admission.

Autopsy.- $X$ ray of the excised lumbar spine showed narrowing of the 4th disk with herniation into the 4th vertebral body and anterior erosions, but little osteophyte formation or sclerosis.

Histology.-There was rheumatoid arthritis of the apophyseal joints, displacement of the upper chondral plate of the 4th disk, but only minimal callus formation. A histological diagnosis of trauma in a degenerate disk was made. It was thought that hypercorticoidism had played a pait in increasing the liability to trauma.

\section{Discussion}

It is clear from the few autopsy cases we have studied that the lumbar apophyseal joints are affected in rheumatoid arthritis. The radiological studies indicate that the condition can be recognized during life but, although a similar relationship with the SCAT was found for cervical and lumbar rheumatoid arthritis, the diagnosis of the disease in the lumbar spine was in practice found to be more difficult. This was due to the frequent association between disk degeneration and subluxation, a difficulty which arose more especially in males engaged in heavy manual pursuits. In the neck, subluxation due to disk degeneration seldom occurs at the affected disk; more often it is found in that above a narrowed degenerate disk, but the association is nevertheless readily apparent. In the lumbar region subluxation often occurs at the degenerate disk and it is then difficult to determine whether the subluxation is 
simply a result of the degenerative process or whether arthritis is also present and is playing a part. Fortunately there is a negative correlation between rheumatoid arthritis and such features of disk degeneration as anterior wear and sclerosis of the vertebral plates, so that subluxation without these features is more likely to be secondary to a rheumatoid process. Anterior subluxation is in favour of a rheumatoid aetiology since the shape of the uneroded facet is such as to prevent it. Occasionally, however, fracture of the facets may enable anterior subluxation to occur at a degenerate disk. Posterior subluxation is more commonly secondary to disk degeneration.

Another source of difficulty in the lumbar spine is the occurrence of spondylolisthesis which may closely simulate anterior subluxation. Indeed, Newman (1955) includes anterior subluxation associated with osteo-arthrosis of the apophyseal joints as Group IV in his classification of spondylolisthesis. We have limited the term spondylolisthesis to those cases in which the subluxation is associated with a defect in the arch. In such cases the antero-posterior diameter of the vertebra as measurement from the tip of the posterior spinous process to the anterior surface of the body is increased and is found to be out of sequence in this respect with the vertebral body above and below. Moreover the defect in the arch is usually visible.

Erosive changes in the apophyseal joints in lumbar arthritis are seldom clearly defined, and are only rarely of assistance in making a diagnosis of rheumatoid arthritis.

It may be considered whether the association between lumbar arthritis and the SCAT which we have found on 'blind' reading of $x$ rays may have depended on a subconscious linking with osteoporosis. This would seem unlikely since the diagnosis was made more commonly in males and they are less affected by osteoporosis than females. Moreover, a definite grading for spinal osteoporosis was made in only three of the seventeen persons in the random sample who were given a grading of 2 or more for lumbar arthritis.

It has not been possible to define clearly the anatomical changes produced by rheumatoid arthritis in the lumbar spine in this study. The lumbar apophyseal joints are affected in much the same way as other diarthrodial joints in rheumatoid arthritis. Whether these are alone responsible for the radiographic appearances which we have encountered is uncertain. Erosion of facets could explain the anterior subluxations, particularly if associated with damage to the apophyseal ligaments and degenerative change in the corresponding disk, but only if the erosions were present before or in the early stages of the degenerative process, since advanced disk degeneration results in increased stability of the affected segments of the spine. Disk narrowing in the absence of hypertrophic change is more difficult to explain. We have no definite evidence that the disk is involved in an erosive process. In histological studies of the cervical spine the disk was commonly eroded by granulation tissue arising from the neuro-central joints (Ball, 1958). In four lumbar spines from rheumatoid patients which we have studied at autopsy, the disk narrowing was in three instances due to disk degeneration and in the fourth was attributed to trauma acting on the disk of a hypercorticoid individual. One possible explanation of the characteristic radiographic appearance is that, in rheumatoid subjects, disk degeneration when present does not give rise to the same degree of bony reaction as in non-rheumatoid persons, whether as a result of some metabolic defect or simply because rheumatoid subjects do not move their spines so much.

This study brings out the differences which have been emphasized on other grounds between rheumatoid arthritis and ankylosing spondylitis. Bridging of disk spaces was no more frequent in the rheumatoid than in the non-rheumatoid subjects, and was in all instances of the type found in senile ankylosing hyperostosis. We have only once recognized bony ankylosis of lumbar apophyseal joints in a rheumatoid spine. The relevance of rheumatoid arthritis in the lumbar spine to clinical practice is not great since in many instances local symptoms are lacking, but the diagnosis should be considered in patients with unexplained sciatic pain, particularly if there is evidence of rheumatoid arthritis elsewhere or if rheumatoid factor is present in the serum. In field surveys of rheumatoid arthritis, an $x$ ray of the lumbar spine will sometimes reveal disease not detected by radiographs of the hands, feet, or cervical spine. Of the 63 persons with radiological evidence of rheumatoid arthritis in the present sample, twelve would have been missed had the lumbar spine been omitted. None of these twelve had a positive SCAT and only one had clinical evidence of polyarthritis, but a history of back and leg pain was given by four, of lumbar pain by three, and of leg pain by two.

If both the cervical and lumbar spine are affected by rheumatoid arthritis it would be reasonable to suppose that the dorsal spine may also be involved. Though we have studied a series of lateral $x$ rays of the dorsal spine with this in mind, no pathognomonic changes have been found. The only radiological change which was encountered more frequently in persons with rheumatoid arthritis or with 
a positive SCAT was osteoporosis. It would seem that the supporting effect of the thoracic cage and the thinner disks in this region prevent subluxation and reduce any instability which might otherwise arise. Radiographs designed to show costo-vertebral joints might be more revealing, but these were not used in this study.

\section{Summary}

A series of lateral radiographs of the lumbar spine from subjects aged 55 to 64 years with rheumatoid arthritis and/or a positive SCAT have been compared with a series of spines from non-rheumatoid controls of the same age and sex.

Subluxation, disk narrowing without vertebral osteophytosis, apophyseal erosions, and osteoporosis were more common in the rheumatoid group. Sclerosis and anterior wear of the vertebral plates were more common in the non-rheumatoid group.

These criteria were used to grade a series of lumbar $x$ rays from random population samples for rheumatoid arthritis. By these criteria lumbar rheumatoid arthritis was present in 5 per cent. of males and in 3 per cent. of females. A relationship was found between lumbar rheumatoid arthritis and the sheep cell agglutination titre, erosive arthritis of the hands and feet, and rheumatoid arthritis of the cervical spine.

Autopsy findings in the lumbar spines of four patients with rheumatoid arthritis are reported.

We wish to express our thanks to Prof. J. H. Kellgren and Prof. E. G. L. Bywaters for permission to study $x$ rays of patients.

\section{REFERENCES}

Baggenstoss, A. H., Bickel, W. H., and Ward, L. E. (1952). J. Bone Jt Sur., 34A, 601.

Ball, J. (1958). Ann. rheum. Dis., 17, 121.

Cochran, W. G. (1954). Biometrics, 10, 417.

Forestier, J., and Rotes-Quérol, J. (1950). Ann. rheum. Dis., 9, 321.

Kellgren, J. H. (1939). Clin. Sci., 4, 35. (1940). Ibid., 4, 303.

and Lawrence, J. S. (1952). Brit. J. industr. Med., 9, 197.

Lawrence, J. S. (1955). Ibid., 12, 249.

Lewis, T. (1942). "Pain". Macmillan, New York.

Lorber, A., Pearson, C. M., and Rene, R. M. (1961). Arthr. and Rheum., 4, 514.
Newman, P. H. (1955). Ann. roy. Coll. Surg. Engl., 16, 305.

Seaman, W. B., and Wells, J. (1961). Amer. J. Roentgenol, 86, 241.

Sharp, J. Purser, D. W., and Lawrence, J. S. (1958). Ann. rheum. Dis., 17, 303.

\section{Arthrite rhumatismale de la colonne lombaire}

\section{RÉSUMÉ}

On a comparé une série de radiographies latérales de la colonne lombaire des sujets âgés de 55 à 64 ans, atteints d'arthrite rhumatismale et/ou ayant la réaction de Waaler-Rose positive à une autre série de clichés similaires des témoins non-rhumatisants d'âge et de sexe correspondants.

$\mathrm{La}$ subluxation, le rétrécissement du disque sans ostéophytose vertébrale, l'érosion apophysaire et l'ostéoporose furent plus communs dans le groupe rhumatismal. La sclérose et l'usure antérieure des plaques vertébrales furent plus communes dans le groupe non-rhumatismal.

On se servit de critères ainsi établis pour classer une série de radiographies lombaires provenant d'un échantillon de la population générale. On trouva que l'arthrite rhumatismale lombaire fut présente chez 5 pour cent des hommes et 3 pour cent des femmes. On trouva un rapport entre l'arthrite rhumatismale lombaire et le titre de la réaction de Waaler-Rose, l'arthrite érosive des mains et des pieds et l'arthrite rhumatismale de la colonne cervicale.

On rapporte les résultats d'autopsie de la colonne lombaire de quatre malades atteints d'arthrite rhumatismale.

\section{Artritis reumatoide de la espina lumbar}

\section{SUMARIO}

Se comparó una serie de radiografías laterales de la columna lumbar de sujetos de 55 a 64 años de edad, afectos de artritis reumatoide y/o presentando una reacción de Waaler-Rose positiva a una serie de clisés lumbares de testigos non-reumaticos de edades y sexos correspondientes.

Subluxación, estrechamiento del disco sin osteofitosis vertebral, erosión apofisaria y osteoporosis fueron más comunes en el grupo reumatoide. Esclerosis y desgaste anterior de las placas vetebrales fueron más comunes en el grupo non-reumatoide.

Se emplearon los criterios así establecidos para clasificar una serie de radiografías lumbares de una muestra de la población general. Se halló que la artritis reumatoide lumbar existía en un 5 por ciento de los hombres y en un 3 por ciento de las mujeres Se halló también una relación entre la artritis reumatoide lumbar y el título de la reacción de Waaler-Rose, la artritis erosiva de la mano y del pie y la artritis reumatoide de la columna cervical.

Se relatan los resultados de autopsia de la columna lumbar de cuatro enfermos con artritis reumatoide. 